\title{
Do partly outdated palaeontological data produce just a noise? An assessment of the Middle Devonian- Mississippian biodiversity dynamics in central Asia on the basis of Soviet-time compilations
}

\author{
Dmitry A. Ruban ${ }^{1,2}$ \\ ${ }^{1}$ Division of Mineralogy and Petrography, Geology and Geography Faculty, Southern Federal University, \\ Zorge Street 40, Rostov-na-Donu, 344090, Russian Federation; e-mail: ruban-d@mail.ru, ruban-d@rambler.ru \\ ${ }^{2}$ Address for contact by post: P.O. Box (a/jashik) 7333, Rostov-na-Donu, 344056, Russian Federation
}

\begin{abstract}
Interregional tracing of trends and events in the biotic evolution is an important task of modern palaeobiology. In Soviet times (1917-1991), numerous palaeontological data have collected for the territory of Russia and neighbouring U.S.S.R. countries. Later, these data were compiled and published in a series of reference volumes. Although this information cannot be updated in a conventional way, it remains valuable for quantitative analyses, particularly because of its comprehensive and unique character. Assessment of the previously collected data on the stratigraphic distribution of Middle Devonian-Mississippian marine invertebrates in three regions of central Asia (central Kazakhstan, Uzbekistan and Tajikistan) reveals some general patterns of biodiversity dynamics. The total number of genera generally declined during the Givetian-Famennian, whereas a remarkable diversity peak occurred in the Visean. This is consistent with the global pattern and, thus, permits to hypothesize a regional signature of the global trends. Changes in the extinction rate differ, however, between central Asia and the Earth in its entirety, which may be explained particularly by biases in either the regional or the global records. Evidence of the Givetian and Frasnian/Famennian mass extinctions is found in the three regions under study. Results of this tentative study indicate important directions for further research and suggest that central Asia is a highly important domain for studies of mid-Palaeozoic biodiversity dynamics.
\end{abstract}

Keywords: palaeontological data; palaeobiodiversity, mass extinctions, Middle Devonian, Late Devonian, Mississippian, central Asia

\section{Introduction}

Quantitative assessment of biodiversity remains the principal direction of modern palaeobiology. It allows to recognize both some main evolutionary trends and key events (radiations, mass extinctions, major turnovers, etc.) in the history of life. The studies by Sepkoski et al. (1981), Sepkoski (1993), Benton (2001), Pe- ters \& Foote (2001), and Purdy (2008) demonstrated the efficacy of this approach on a global scale. However, the reconstructed patterns of palaeobiodiversity dynamics require an accurate interregional tracing. This is the case, for example, for the Frasnian/Famennian mass extinction, which is well-documented (Raup \& Sepkoski, 1982; Buggisch, 1991; McGhee, 1996; Hallam \& Wignall, 1997; House, 2002; Purdy, 
2008), but still lacks an adequate place in the context of different palaeogeographical domains (Racki, 2005).

When analysis of new palaeontological data contributes to the quantitative assessment of palaeodiversity, older - possibly partly outdated - data from poorly known regions should not be abandoned. In the former U.S.S.R, a huge amount of high-quality (by the then standards) information about the stratigraphic distribution of fossils had accumulated. An important tradition of the Soviet time (1917-1991) geoscience was the publication of compilations of the available geological and palaeontological data under supervision of top professionals. Examples of such compilations are the dozens of volumes in the series 'Geology of the USSR', 'Stratigraphy of the USSR', etc., as well as numerous descriptive notes supplied to geological maps and stratigraphical correlations tables that were published with open access. They have remained inaccessible for the international scientific community, however, because of their publication in Russian. These publications should nevertheless still be regarded as precious sources of information, ready for palaeobiological assessment.

Unfortunately, part of these compilations are now partly outdated. As they contain only taxonomic lists without descriptions and illustrations, it seems difficult, if possible at all, to check the correct identification of specimens and - if necessary - to improve them. It might be argued that any new analysis of these old

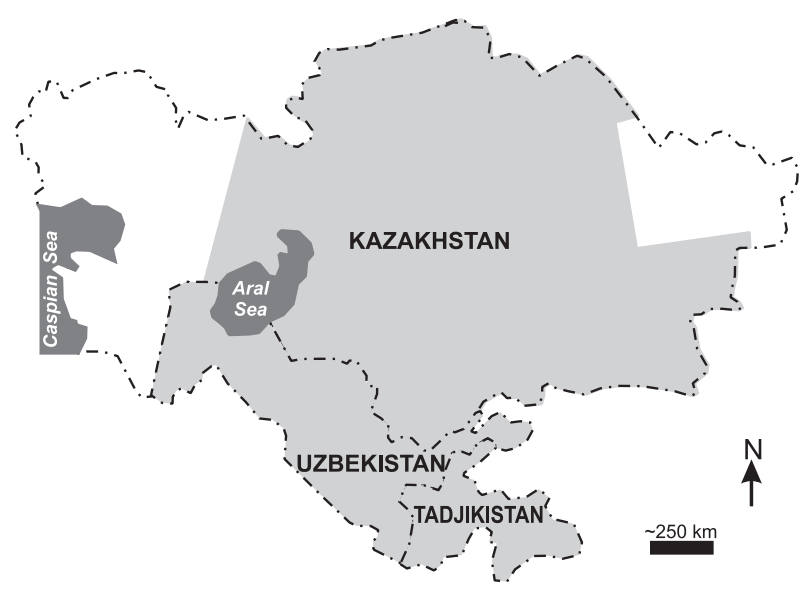

Fig. 1. Location of the territory considered in the present study (shaded in light grey). data will produce just a noise, but such a judgment seems unjustified. The comprehensiveness of the compilations and their contents of high-quality data, which would otherwise never be updated, requires consideration of the question whether they should not deserve to become included in present-day studies. Of course, many other monographs and compendia including taxonomic descriptions and illustrations were published in Soviet times (e.g., Morozova, 1970; Grunt \& Dmitriev, 1973), but there is no guarantee that they include all taxa from the above-mentioned compilations, and relationships between the various information sources can therefore not always be traced. One might thus state that comprehensive publications without taxonomic descriptions and illustrations on the one hand and palaeontological monographs on the other hand are different sources of information for palaeobiodiversity investigations. Specialists in the systematics and palaeobiology of particular fossils groups will, indeed, prefer 'classical' monographs, but more general palaeobiologists should not leave the other compilations unstudied.

The present contribution has two objectives. First, it aims at demonstrating a possible way to use the palaeontological data from Soviet time. Second, it provides an example of such an analysis, which deals with information on Middle Devonian to Mississippian (397.5$318.1 \mathrm{Ma})$ marine invertebrates from central Asia, more specifically central Kazakhstan, Uzbekistan and Tajikistan (Fig. 1). This example will show that these partly outdated data can help to recognise regional signatures of global trends and events.

\section{Geological setting}

The palaeontological information considered in the present contribution characterizes a large region delimited by political boundaries. It is thus related to particular countries, rather than to geological domains. It should be noted, however, that the occurrence of most of the Middle Devonian-Mississippian fossils treated in the present analysis are connected in the original data sources to major tectonic 
structures, which simplifies the task of geological delineation of the study area.

Geographically, the study area embraces the central part of Kazakhstan and entire Uzbekistan and Tajikistan (Fig. 1). Geologically, this territory is highly diverse and it comprises several structural domains; the most important ones are the Kazakh terranes, the Tien Shan (western part), and the Pamirs. Devonian and Carboniferous deposits, both marine and terrestrial, are extensive (Zhamojda, 1968; Nalivkin et al., 1973; Baratov, 1976; Tuljaganov \& Jaskovitch, 1980; Bespalov \& Kostenko, 1981a,b; Orlov \& Bespalov, 1981). The various units have different lithologies, thickness, and facies (Fig. 2). Generally, these deposits are mixed siliciclastics, carbonates (less frequent), and volcanics/volcaniclastics in the MiddleUpper Devonian interval and carbonates with some siliciclastics in the Mississippian interval. The proportion of carbonates increases southwards, and this lithology dominates the entire Middle Devonian-Mississippian succession in the central Pamirs. Unfortunately, the lack of appropriate plate-tectonic reconstructions (see below) prevents the precise reconstruction in time and space of the sedimentary and palaeogeographical development of central Asia.

Regarding palaeotectonics, central Asia is a heterogenous region. The available plate-tectonic reconstructions (Şengör \& Natal'in, 1996; Kalvoda, 2002; Bazhenov et al., 2003; Stampfli \& Borel, 2002; Buslov et al., 2004; Scotese, 2004; Torsvik \& Cocks, 2004; Ruban et al., 2007; Abrajevitch et al., 2008; Biske \& Seltmann, 2010) leave some uncertainty with respect to their nature, which is especially well-demonstrated in the syntheses by Torsvik \& Cocks (2004) and Ruban et al. (2007). The nomenclature of terranes is yet to be developed, and even an approximate relative position of tectonic blocks in the mid-Paleozoic remains debated or simply unclear. It seems that central Kazakhstan, Uzbekistan, and Tajikistan constitute collages of terranes (many are small in size), which formed gradually through the Paleozoic-Mesozoic. The Kazakh terranes were a particular tectonic domain, whereas many other terranes were parts of terrane chains (like Hun, Cimmeria) delivered from the Gondwanan margin of the Tethyan oceans (Proto-Tethys, Palaeo-Tethys, Neo-Tethys) to the Laurussian margin. In the

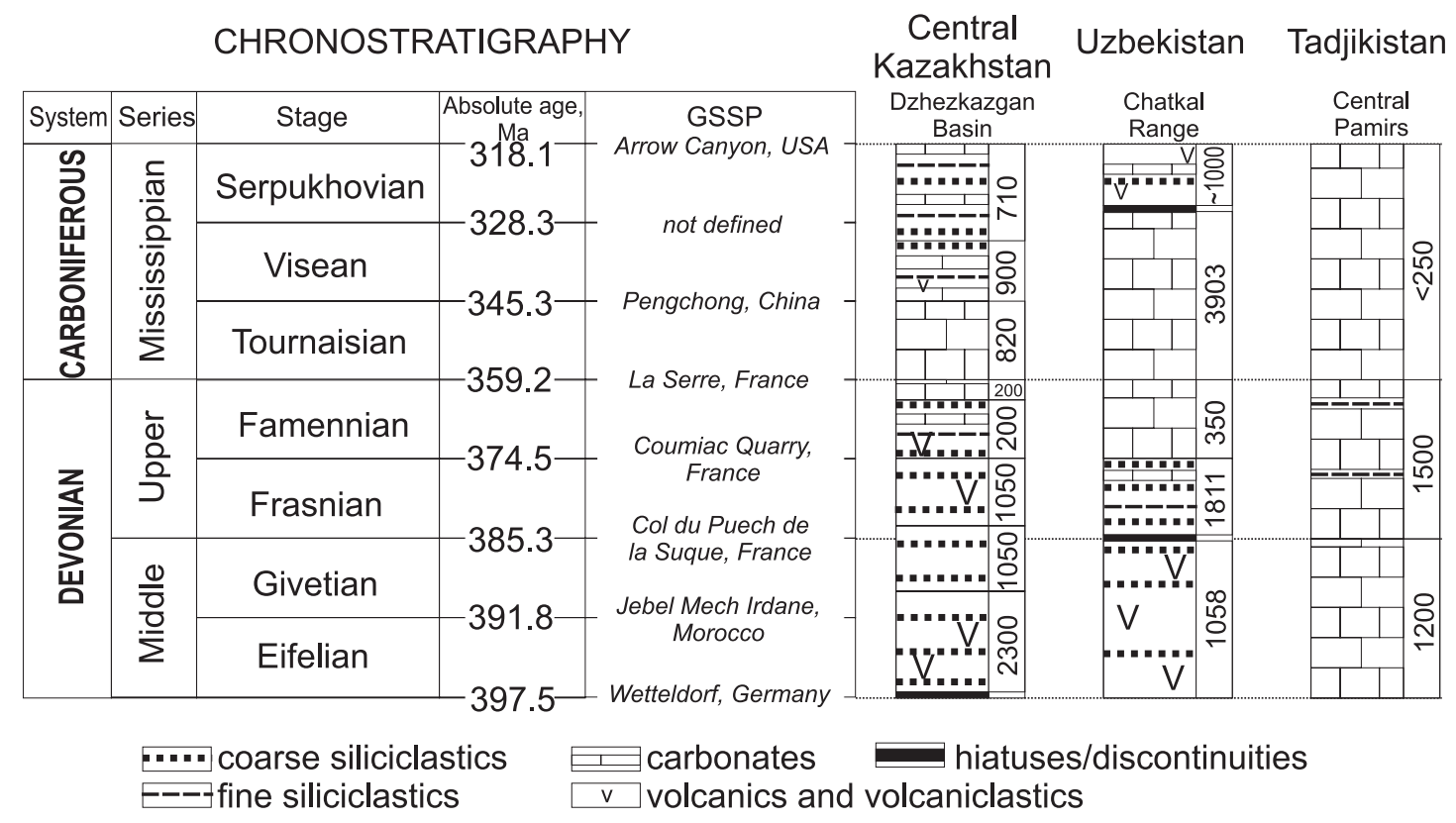

Fig. 2. Chronostratigraphy of the Middle Devonian-Mississippian interval (after Ogg et al., 2008) and correlation of some representative composite sections of central Asia (regional stratigraphic data are taken from Baratov, 1976; Tuljaganov \& Jaskovitch, 1980; Orlov \& Bespalov, 1981). Thickness (in metres) is indicated to the right of the columns. 
Middle Devonian-Mississippian, the Kazakh terranes were situated between the KhantyMansi, Asiatic and Palaeo-Tethys oceans. Some other terranes were probably already attached to Laurussia, whereas others were still anchored in the vicinity of Gondwana.

\section{Material and methods}

The Soviet-time palaeontological compilations often look like stage-by-stage or formation-by-formation lists of taxa (either all known or the most common). It should be noted that commonly no occurrence of a particular taxon is mentioned for a particular section. Although this complicates the stratigraphical and 'pure' palaeontological use of these compilations, these regional datasets are advantageous rather than disadvantageous for palaeobiodiversity assessments, as data from a relatively large region are evidently always more complete than those from an individual section. There are, however, also some pitfalls for the quantitative treatment of the Soviet-time palaeontological compilations.

First, the data are usually partly outdated in terms of both fossil systematics and stratigraphic framework. The absence of plates with fossil figures as well as of references to the original taxonomic descriptions and/or collections prevents checking of these data, and the only possible way is to use them 'as is', taking the possible uncertainties for granted. The stratigraphic framework can, fortunately, commonly be correlated with the modern chronostratigraphy.

Second, the data may be affected by 'artificial' taxonomy. The Soviet scientific community was largely isolated from the international community, and specialists didn't have free access to all publications and all collections in the western world. Consequently, some taxa received names different from those adopted by specialists from other countries, whereas some other taxa were subdivided with more or less precision than necessary. This problem was particularly typical for species, as suggested by the present author's experience with data revision, and it can be solved by considering only genera and higher taxa.
Third, although the Soviet-time palaeontological compilations generally do not suffer from sampling deficiencies (broad regionalscale palaeontological investigations were common during Soviet times), they may be incomplete. Two types of such incompleteness can be distinguished. The first type is, as mentioned above, that only common taxa were sometimes considered in the compilations. This may or may not be truly important in palaeobiodiversity assessments: as shown by Ruban (2005), the very outdated and very incomplete datasets that record the most common fossils that were available already in the mid-19 $19^{\text {th }}$ century, tend to allow recognition of some of the key trends and events in the Mesozoic biodiversity dynamics that are known today. The second type of incompleteness is related to the common impossibility to incorporate data from the compilations in data sets accumulated later. Additionally, biases linked to facies distribution and rock volume, which are common for many fossil records (e.g., Krug \& Patzkowsky, 2005; Wall et al., 2009), cannot always be avoided.

The above-mentioned pitfalls diminish the usability of palaeontological information from the Soviet-time compilations, but do not imply that these compilations are not unique or can be re-placed by any comparable dataset. Obviously, no guarantee exists that all fossils of which the names exist in the compiled lists, can be re-sampled, because this is impossible or almost each palaeontological field study. The compilations thus should be considered as a basis for a peculiar type of assessment of biodiversity dynamics.

When the partly outdated data sets are used, however, without mentioning in how far are they outdated or correct, the measured changes in the fossil numbers can be treated for hypothetical models of biodiversity dynamics only. If the recorded pattern is consistent with that known from the global or any other well established regional record, it may be assumed that the 'old' data are not only principally correct, but also provide new evidence. If, on the other hand, no consistency is present, this means that either the data are invalid or a regional signature of a large-scale trend or 
REGIONAL VERSUS GLOBAL PATTERNS

1. patterns coincide

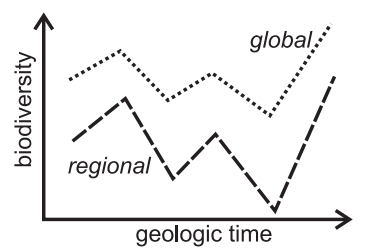

2. patterns do not coincide

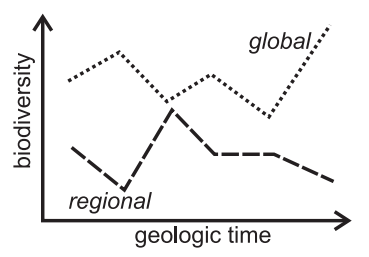

NOTE: presence/absence of coincidence may be also just haphazard!

\section{INTERPRETATIONS}

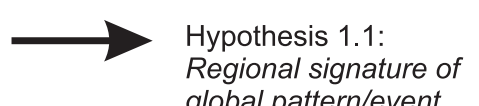
global pattern/event
Fig. 3. Consistency of regional and global palaeobiodiversity patterns and its possible interpretation in the case of partly outdated data. event is absent. one should also keep in mind, however, that it is likely that global mass extinctions were heterogeneous in space, and that they thus might either appear in particular regions or not (Krug \& Patzkowsky, 2007; Bonelli \& Patzkowsky, 2008; Jablonski, 2008). The interpretation of biodiversity dynamics on the basis of the Soviet-time palaeontological compilations therefore allows some hypotheses (Fig. 3) which require further testing. These hypotheses may be crucial for interregional tracing of trends and events in the absence of other reliable evidences from major regions.

The present contribution deals with palaeontological data concerning the Middle Devonian-Mississippian marine invertebrates from central Kazakhstan, Uzbekistan, and Tajikistan. These data were originally published in descriptive notes to maps of the above territories by Baratov (1976), Tuljaganov \& Jaskovitch (1980), Bespalov \& Kostenko (1981a,b), and Orlov \& Bespalov (1981). It is not the intention to include here all available palaeontological information from the study areas, but to give examples of the usability of the Soviet-time compilations. The five just-mentioned studies have been chosen at random. Exceptions are the volumes by Bespalov \& Kostenko $(1981 a, b)$ and Orlov \& Bespalov (1981), which constitute a single dataset relevant to one region, but divided over three portions. Of course, other specialists might choose different compilations, and, if doing so, they might take advantage of the present contribution that provide them with a simple template for the purpose.

The distribution of genera per stage was compiled here from these sources 'as is', i.e., without corrections. A total of 338 genera from central Kazakhstan, 188 genera from Uzbekistan, and 141 genera from Tajikistan are considered in Appendices 1-3 of the abovementioned works, in which the occurrence of a genus in a stage is weighed with a value of 1.00. Some taxa occur in formations of which the age is defined as a range, e.g., Frasnian-Famennian. In such a case, an equal probability of genus occurrence in each stage of the given range is presumed. If a genus is indicated for a formation which is Frasnian-Famennian in age, the occurrence of this genus in the Frasnian is weighed with the value 0.5 , and the same value is assigned to the Famennian. This 
probabilistic approach may bring some uncertainty but allows to deal with the original data properly.

Two patterns are measured in this study. These include the total biodiversity dynamics, which is calculated as the total number of genera in the various stages, and the extinction rate, which is calculated as the number of genera that disappear in a stage and that do not reappear later during the studied time interval. It should be noted that this study deals with more or less true taxa extinctions, not temporary disappearances. As no data for the post-Mississippian are involved, the extinction rate cannot be measured for the Serpukhovian (see Ruban \& Van Loon, 2007, for an explanation). The regional patterns are further compared with the global ones that were recorded by Purdy (2008), whose assessment of the global biodiversity dynamics at a generic level is based on the famous database by Sepkoski (2002). This comparison makes it possible to hypothesize about a possible regional signature of global trends and events, taking into account all possible uncertainties in the available palaeontological data. Although the database by Sepkoski (2002) may be judged outdated, alternative constraints by Alroy et al. (2008) involve some other approach (data modelling), and it is consequently questionable whether these new palaeobiodiversity estimates are compatible with the results of a regional study like this.

The Soviet-time compilations used for the purposes of this study are based on a regional stratigraphic framework, which does not differ significantly from the modern chronostratigraphy detailed by Ogg et al. (2008). The only major difference occurs in the late Mississippian. The stratigraphic intervals of the Visean and Serpukhovian stages mentioned here may be slightly different from the time intervals of these stages in the modern geological time scale.

\section{Results}

The available data allow to hypothesize about significant changes in the total diversity of marine invertebrates during the Middle
Devonian-Mississippian in central Asia (Fig. 4; Table 1). A slight increase in the number of genera in the Givetian, followed by a similarly weak decline in the Frasnian-Famennian and a diversity peak in the Tournaisian-Visean, are found for central Kazakhstan. Comparable developments are found for Uzbekistan and Tajikistan, but with some exceptions: in none of these two regions, the Givetian shows a rise in diversity, and in Tajikistan the marine fauna began to radiate already in the Famennian, and not in the Tournaisian as in central Kazakhstan and Uzbekistan. Such a similarity of three regional curves delineated on the basis of different datasets itself implies a reliable reconstruction. The global changes in marine biodiversity through the same time interval include an Eifelian-Famennian decline in the total number of genera and a Visean diversity peak (Purdy, 2008). This pattern roughly matches the regional biodiversity dynamics measured with the Soviet-time data from central Asia (Fig. 4). The only principal difference concerns the proportions of the curves. Whereas the $\mathrm{Vi}$ sean diversity of marine invertebrates exceeds more or less significantly that of the Givetian in central Kazakhstan, Uzbekistan and Tajikistan, the global data (Purdy, 2008) indicate a compa-

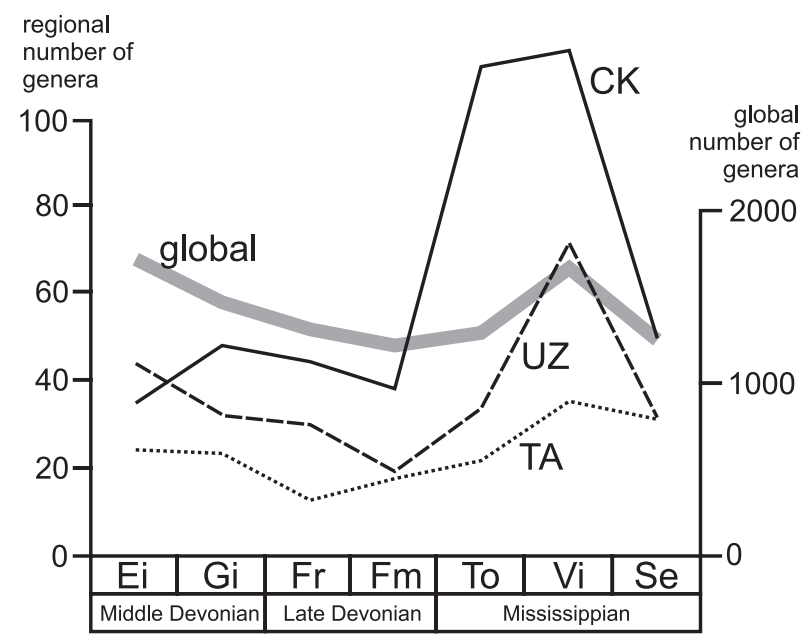

Fig. 4. Total global and central Asian marine Middle Devonian-Mississippian biodiversity dynamics. The global palaeobiodiversity is given roughly after Purdy (2008), whose measurements are based on data compiled by Sepkoski (2002).

$\mathrm{CK}=$ central Kazakhstan, UZ = Uzbekistan, $\mathrm{TA}=$ Tajikistan; Ei = Eifelian, $\mathrm{Gi}=$ Givetian, $\mathrm{Fr}=$ Frasnian, $\mathrm{Fm}=$ Famennian, $\mathrm{To}=$ Tournaisian, $\mathrm{Vi}=$ Visean, $\mathrm{Se}=$ Serpukhovian. 
Table 1. Total marine Middle Devonian-Mississippian biodiversity (number of genera) in central Asia. Some values are incomplete because of probabilistic approach used in this study; see text for more explanations.

\begin{tabular}{lccccccc}
\hline & Eifelian & Givetian & Frasnian & Famennian & Tournaisian & Visean & Serpukhovian \\
\hline central Kazakhstan & 35.00 & 48.00 & 44.50 & 38.30 & 111.80 & 116.00 & 50.00 \\
Uzbekistan & 44.05 & 31.65 & 29.45 & 18.95 & 33.50 & 71.50 & 31.00 \\
Tajikistan & 24.10 & 23.00 & 12.50 & 17.50 & 21.50 & 35.25 & 31.50 \\
\hline
\end{tabular}

rable number of genera for these time intervals (Fig. 4).

The above considerations allow an interpretation of the regional evidence from the central Asian regions on the basis of the above-mentioned conceptual assumptions (Fig. 3). The similarity of the regional biodiversity dynamics with the global one allows to hypothesize

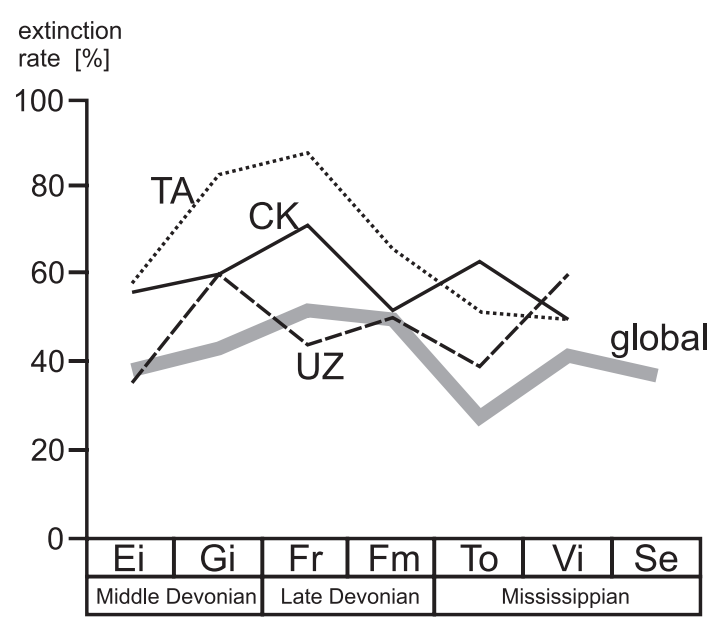

Fig. 5. Extinction rate (number of genera that became extinct during the stage divided through the total generic diversity of this stage * $100 \%$ ) among Middle Devonian-Mississippian marine fossils in central Asia and globally. The global extinction rate is calculated roughly on the basis of the results of Purdy (2008), whose measurements are based on data compiled by Sepkoski (2002). See Figure 4 for abbreviations of regions and stages. that even partly outdated palaeontological data can indicate a regional signature of the global patterns. This implies that the fossil records of central Kazakhstan, Uzbekistan and Tajikistan are potentially very important for tracing trends and events in the Middle Devonian-Mississippian dynamics of the marine invertebrate biodiversity.

The available data also allow to hypothesize about not less strong and even more frequent changes in the extinction rate among marine invertebrates in central Asia during the Middle Devonian-Mississippian (Fig. 5; Table 2). In Central Kazakhstan, the peaks of extinctions were reached in the Frasnian and the Tournaisian. In Uzbekistan, such peaks are found for the Givetian, the Famennian, and the Visean. In Tajikistan, only one peak occurs, viz. in the Frasnian, preceded by a very high extinction rate in the Givetian. The compiled Soviet-time palaeontological data from central Asian regions therefore do not allow to identify any common pattern of the extinction rate. In the global record, the number of extinctions was highest in the Frasnian, and it remained high in the Famennian before it accelerated further the Visean (Purdy, 2008). Such a pattern does not match completely any regional pattern (Fig. 5). the lack of consistency of the involved curves leads to several hypothesis (Fig. 3). A weak (if

Table 2. Number of generic extinctions and extinction rate (number of genera went extinct during the stage / total generic diversity of this stage * $100 \%$ ) among Middle Devonian-Mississippian marine fossils in central Asia. Some values are incomplete because of probabilistic approach used in this study; see text for more explanations.

\begin{tabular}{lccccccc}
\hline & Eifelian & Givetian & Frasnian & Famennian & Tournaisian & Visean & Serpukhovian \\
\hline \multirow{2}{*}{$\begin{array}{l}\text { central Kazakhstan } \\
\text { Uzbekistan }\end{array}$} & 19.5 & 29.0 & 31.5 & 20.00 & 70.8 & 58.5 & - \\
Tajikistan & 15.5 & 19.1 & 13.0 & 9.45 & 13.0 & 43.0 & - \\
\hline & 14.0 & 19.0 & 11.0 & 11.50 & 11.0 & 17.5 & - \\
central Kazakhstan & 56.0 & 60.0 & 71.0 & 52.00 & 63.0 & 50.0 & - \\
Uzbekistan & 35.0 & 60.0 & 44.0 & 50.00 & 39.0 & 60.0 & - \\
Tajikistan & 58.0 & 83.0 & 88.0 & 66.00 & 51.0 & 50.0 & - \\
\hline
\end{tabular}


any) appearance of the global trends and events cannot be explained by palaeoenvironmental specificity, because the same specificity would restrict in this case a regional appearance of the total biodiversity changes. It is more likely that either the global diversity dynamics of marine invertebrates during the Middle DevonianMississippian had a mechanism (balance between new appearances and extinctions) that was different in space - i.e., biodiversity changes were spatially complex in terms of Jablonski (2008) or the regional data are so biased that they do not allow a correct interpretation. It is worth mentioning here that the extinction rate is difficult to be reconstructed correctly (e.g., Boucot, 2006), and thus an incorrect picture of both the regional and global records cannot be excluded.

A particular feature of the Middle Devonian-Mississippian was a series of mass extinctions. This fact makes any new assessment of biodiversity dynamics for this time interval truly important. It may be true that it is justified that the Frasnian/Famennian catastrophe is the most well-known (Copper, 1977, 1986; 2002; Raup \& Sepkoski, 1982; Becker et al., 1991; Buggisch, 1991; Wang et al., 1991 Becker \& House, 1994; McGhee, 1996; Hallam \& Wignall, 1997; House, 2002; Racki et al., 2002;
Racki, 2005; Bambach, 2006; Purdy, 2008), but two other biotic collapses should not be neglected. These took place during the Givetian (Taghanic) (Walliser, 1996; House, 2002) and the Devonian/Carboniferous; the latter is somewhat undervalued (Racki 2005) but nevertheless a true mass extinction (Hallam \& Wignall, 1997; Caplan \& Bustin, 1999; House, 2002). The Soviet-time data from central Asia and the above-mentioned assessment of biodiversity performed on their basis (Figs. 4,5 ) justify questioning the regional signature of these three events (Table 3 ). In the just-mentioned literature on these events, two kinds of evidence of a biotic collapse are considered, namely a decrease in the total diversity after the events (i.e., in the succeeding stage), and acceleration of the extinction rate contemporaneously with the event (i.e., in the same stage).

Our analysis supports the hypothesis that more or less clear evidence of the Givetian mass extinction is available from all central Asian regions under consideration here, being strongest for Tajikistan. The Frasnian/Famennian mass extinction is also recorded elsewhere, but somewhat weaker. It appears that this biotic catastrophe was the most severe in central Kazakhstan. The Devonian/Carboniferous event is not documented in the available datasets,

Table 3. Evidence of mass extinction and biotic crises among marine invertebrates in central Asia.

\begin{tabular}{|c|c|c|}
\hline Mass extinctions/biotic crises & $\begin{array}{c}\text { Decrease in total generic diversity } \\
\text { after the event }\end{array}$ & $\begin{array}{l}\text { Increase in extinction rate contempo- } \\
\text { raneously with the event }\end{array}$ \\
\hline & central Kazakhstan & \\
\hline Givetian & minor & minor \\
\hline Frasnian/Famennian & minor & $\begin{array}{l}\text { minor } \\
\text { (but extinction rate was the highest) }\end{array}$ \\
\hline \multirow[t]{2}{*}{$\begin{array}{l}\text { Devonian/Carboniferous (Famen- } \\
\text { nian/Tournaisian) }\end{array}$} & no & no \\
\hline & Uzbekistan & \\
\hline Givetian & not significant & significant \\
\hline Frasnian/Famennian & significant & no \\
\hline $\begin{array}{l}\text { Devonian/Carboniferous (Famen- } \\
\text { nian/Tournaisian) }\end{array}$ & no & minor \\
\hline Givetian & $\begin{array}{l}\text { Tajikistan } \\
\text { significant }\end{array}$ & significant \\
\hline Frasnian/Famennian & no & $\begin{array}{c}\text { minor } \\
\text { (but extinction rate was the highest) }\end{array}$ \\
\hline $\begin{array}{l}\text { Devonian/Carboniferous (Famen- } \\
\text { nian/Tournaisian) }\end{array}$ & no & $\begin{array}{c}\text { no } \\
\text { (but extinction rate remained rela- } \\
\text { tively high) }\end{array}$ \\
\hline
\end{tabular}


although some weak indications of this event are found in Uzbekistan and Tajikistan. One should note, however, that the extinction rate revealed by the partly outdated data seems questionable (see above), and that the ultimate evidence in all cases is therefore the signal provided by changes in the total diversity of marine invertebrates. If only these changes are taken into account, one may conclude that the Givetian and the Frasnian/Famennian mass extinctions left an imprint, indeed, on the biotic evolution in central Asia. This evidence of these global events validates the analytical results of the partly outdated regional records and makes them potentially important for the global mapping of these mass extinctions.

The absence or weakness of the Devonian/ Carboniferous event in the regional records may by interpreted following one of four possible hypotheses suggested for such a case (see Fig. 3). It is sensible to add here that this event might have been a short-term phenomenon and that a stage-by-stage calculation as carried out here consequently does not document it. This hypothesis seems to be realistic, because the biodiversity curve proposed by Purdy (2008), which has the same resolution as our regional curves, does not indicate any diversity decline linked with the Devonian/Carboniferous mass extinction. Purdy (2008) reports, however, a high extinction rate in the Famennian. It is worthwhile mentioning that the latter event has also been recorded by other studies (Racki, 2005, 2009; Bambach, 2006).

Although the valuation of influences of regional factors and preservation peculiarities on palaeobiodiversity estimates is not on objective of the present contribution, it should be noted here that the relatively higher diversity in the Mississippian stages (Fig. 4) coincides with extensive carbonate deposition (Fig. 2). If carbonate successions are more complete (because of palaeoenvironments favourable for both carbonate production and growth or better preservation of organisms), the evidence from Tajikistan seems to be the most realistic, because Middle Devonian-Mississippian sedimentary successions of this region are dominated by carbonates (e.g., Baratov, 1976).

\section{Discussion}

The assessment of Middle Devonian-Mississippian biodiversity dynamics in central Asia on the basis of Soviet-time compilations led to the above hypotheses. The next question concerns the usability of these hypotheses. The similarity of the regional and global curves (Fig. 4) suggests that the global patterns left there signals also in central Asia. Taking into account the palaeotectonic position of these terranes (central Kazakhstan, Uzbekistan and Tajikistan) at the margins of three large oceans (Şengör \& Natal'in, 1996; Kalvoda, 2002; Bazhenov et al., 2003; Stampfli \& Borel, 2002; Scotese, 2004; Torsvik \& Cocks, 2004; Ruban et al., 2007; Abrajevitch et al., 2008; Biske \& Seltmann, 2010), it may be presumed that the ecosystems of these oceans experienced the same biotic changes as elsewhere. Moreover, the mutual resemblance of the biodiversity-dynamics patterns in these regions (Fig. 4) implies the absence of significant differences in biodiversity dynamics between the northern and southern margins of the Palaeo-Tethys. The global signatures of the Frasnian/Famennian mass extinction were mapped by Racki (2005). Evidence of this catastrophe comes from North America, western Europe, southern China and western Australia, but the remaining 'blank space' is still very large. The hypothesis about a regional signature of the Frasnian/Famennian event in central Asia therefore fills a huge gap in the palaeogeographical tracing of this mass extinction, even though some previous studies (e.g., Veimarn et al., 1997) already reported some relevant events. The Givetian mass extinction is less known, and our hypothesis about its regional signature in central Asia consequently supports its actual occurrence.

All above hypotheses require, obviously, further testing. Assessment of the Soviet-time palaeontological compilations provides just tentative regional evidence of biodiversity changes and mass extinctions, but it also indicates directions for further research. With new information about the possible presence/absence of global trends and events in particular regions, it is easier to focus future investiga- 
tions on similarities and discrepancies between the regional and global fossil records.

\section{Conclusions}

Soviet-time palaeontological compilations provide data that allow to perform (or to improve) analysis of palaeobiodiversity dynamics. Particularly, these data may facilitate interregional tracing of key trends and events by changes of the number of genera. When regional patterns are consistent with global ones, a regional signature of these trends and events can be hypothesized.

The assessment of the Middle DevonianMississippian biodiversity dynamics in three regions of central Asia on the basis of Soviettime compilations, which involve partly outdated palaeontological data, produces more than just noise. The results of the present study allow to hypothesize about a regional signature of the key global trends of changes in the number of marine invertebrates. Similarly, the results indicate the actual occurrence of the Givetian and Frasnian/Famennian events in central Asia; they thus contribute to their interregional tracing. Changes in the extinction rate are inconsistent if the regions under study are compared with the global data. No evidence of the Devonian/Carboniferous mass extinction is found regionally. All these results suggest directions for further research. Without hypotheses and assumptions (i.e., tentative biodiversity reconstructions) it will, even if the hypotheses will be confirmed only partly by future investigations, be difficult to assign valuable types of biodiversity-dynamics research to the three regions of central Asia.

\section{Acknowledgements}

The author gratefully thanks J. Fedorowski (Poland) and G. Racki (Poland) for their thorough consideration of the manuscript and for their valuable suggestions. The help with literature provided by N.M.M. Janssen (Netherlands), W. Riegraf (Germany), and several other colleagues is highly appreciated.

\section{References}

Abrajevitch, A., Van der Voo, R., Bazhenov, M.L., Levashova, N.M. \& McCausland, P.J.A., 2008. The role of the Kazakhstan orocline in the late Paleozoic amalgamation of Eurasia. Tectonophysics 455, 61-76.

Alroy, J., Aberhan, M., Bottjer, D.J., Foote, M., Fürsich, F.T., Harries, P.J., Hendy, A.J.W., Holland, S.M., Ivany, L.C., Kiessling, W., Kosnik, M.A., Marshall, C.R., McGowan, A.J., Miller, A.I., Olszewski, T.D., Patzkowsky, M.E., Peters, S.E., Viller, L., Wagner, P.J., Bonuso, N., Borkow, P.S., Brenneis, B., Clapham, M.E., Fall, L.M., Ferguson, C.A., Hanson, V.L., Krug, A.Z., Layou, K.M., Leckey, E.H., Nürnberg, S., Powers, C.M., Sessa, J.A., Simpson, C., Tomašových, A. \& Visaggi, C.C., 2008. Phanerozoic trends in the global diversity of marine invertebrates. Science 321, 97-100.

Bambach, R.K., 2006. Phanerozoic biodiversity and mass extinctions. Annual Review of Earth and Planetary Sciences 34, 127-155.

Baratov, R.B. (Ed), 1976. Rastchlenenije stratifitsirovannykh i intruzionykh obrazovanij Tadzhikistana [Subdivision of stratified and intrusive bodies of Tajikistan]. Donish, Dushanbe, 268 pp. (in Russian)

Bazhenov, M.L., Collins, A.Q., Degtyarev, K.E., Levashova, N.M., Mikolaichuk, A.V., Pavlov, V.E. \& Van der Voo, R., 2003. Paleozoic northward drift of the North Tien Shan (central Asia) as revealed by Ordovician and Carboniferous palaeomagnetism. Tectonophysics 366, 113-141.

Becker, R.T. \& House, M.R., 1994. Kellwasser events and goniatite successions in the Devonian of the Montagne Noire with comments on possible causations. Courier Forschungsinstitut Senckenberg 16, 45-77.

Becker, R.T., House, M.R., Kirchgasser, W.T. \& Playford, P.E., 1991. Sedimentary and faunal changes across the Frasnian/Famennian boundary at the Canning Basin of Western Australia. Historical Biology 5, 183-196.

Benton, M.J., 2001. Biodiversity on land and in the sea. Geological Journal 36, 211-230.

Bespalov, V.F. \& Kostenko, N.N. (Eds), 1981a. Geologitcheskaja karta Kazakhskoj SSR. Serija turgajsko-mugodzharskaja. Ob'jasnitel'naja zapiska [Geological map of the Kazakh SSR. Turgaj-Mugodzhary Series. Descriptive note]. VSEGEI, Alma-Ata, 228 pp. (in Russian)

Bespalov, V.F. \& Kostenko, N.N. (Eds), 1981b. Geologitcheskaja karta Kazakhskoj SSR. Serija juzhnokazakhstanskaja. Ob'jasnitel'naja zapiska [Geological map of the Kazakh SSR. South Kazakhstan Series. Descriptive note]. VSEGEI, Alma-Ata, 324 pp. (in Russian)

Biske, Yu.S. \& Seltmann, R. 2010. Paleozoic Tian-Shan as a transitional region between the Rheic and UralsTurkestan oceans. Gondwana Research 17, 602-613.

Bonelli, R. \& Patzkowsky, M.E., 2008. How are global patterns of faunal turnover expressed at regional scales? Evidence from the Upper Mississippian (Chesterian Series), Illinois Basin, USA. Palaios 23, 760-772.

Boucot, A.J., 2006. So-called background extinction rate is a sampling artifact. Palaeoworld 15, 127-134. 
Buggisch, W., 1991. The global Frasnian-Famennian Kellwasser event. Geologische Rundschau 80, 49-72.

Buslov, M.M., Watanabe, T., Fujiwara, Y., Iwata, K., Smirnova, L.V., Safonova, I.Yu., Semakov, N.N. \& Kiryanova, A.P., 2004. Late Paleozoic faults of the Altai region, central Asia: tectonic pattern and model of formation. Journal of Asian Earth Sciences 23, 655-671.

Caplan, M.L. \& Bustin, R.M., 1999. Devonian-Carboniferous Hangenberg mass extinction event, widespread organic-rich mudrock, and anoxia: causes and consequences. Palaeogeography, Palaeoclimatology, Palaeoecology 148, 187-208.

Copper, P., 1977. Paleolatitudes in the Devonian of Brazil and the Frasnian-Famennian extinction event. Palaeogeography, Palaeoclimatology, Palaeoecology 21, 165-207.

Copper, P., 1986. Frasnian-Famennian mass extinction and cold water oceans. Geology 14, 835-839.

Copper, P., 2002. Reef development at the Frasnian/Famennian mass extinction boundary. Palaeogeography, Palaeoclimatology, Palaeoecology 181, 27-65.

Filippova, L.B., Bush, V.A. \& Didenko, A.N., 2001. Middle Paleozoic subduction belts: the leading factor in the formation of the central Asian fold-and-thrust belt. Russian Journal of Earth Sciences 3, 405-426.

Grunt, T.A. \& Dmitriev, V.Yu., 1973. Permskie brakhiopody Pamira [Permian brachiopods of the Pamirs]. Nauka, Moskva, 212 pp. (in Russian).

Hallam, A. \& Wignall, P.B., 1997. Mass extinctions and their aftermath. Oxford University Press, Oxford, 320 pp.

House, M.R., 2002. Strength, timing, setting and cause of mid-Paleozoic extinction. Palaeogeography, Palaeoclimatology, Palaeoecology 181, 5-25.

Jablonski, D., 2008. Extinction and the spatial dynamics of biodiversity. Proceedings of the National Academy of Sciences 105 (Suppl. 1), 11528-11535.

Kalvoda, J., 2002. Late Devonian-Early Carboniferous foraminiferal fauna: zonations, evolutionary events, paleobiogeography and tectonic implications. Folia Facultatis Scientiarum Universitatis Masarykianae Brunensis, Geologia 39, 1-214.

Krug, A. \& Patzkowski, M., 2005. Sampling standardized regional diversity and turnover patterns during the Late Ordovician mass extinction. Geological Society of America, Abstracts with Programs 37 (7), 384.

Krug, A.Z. \& Patzkowsky, M.E., 2007. Geographic variation in turnover and recovery from the Late Ordovician mass extinction. Paleobiology 33, 435-454.

McGhee, G.R., 1996. The Late Devonian mass extinction - the Frasnian-Famennian crisis. Columbia University Press, New York, 303 pp.

Morozova, I.P., 1970. Mshanki pozdnej permi [Late Permian bryozoans]. Trudy Paleontologitcheskogo instituta AN SSSR 122, 3-332.

Nalivkin, D.V., Rzhonsnitskaja, M.A. \& Markovskij, B.P. (Eds), 1973. Stratigrafija SSSR. Devonskaja sistema. Kniga 1 [Stratigraphy of the USSR. Devonian System. Volume 1]. Nedra, Moskva, 520 pp. (in Russian).

Ogg, J.G., Ogg, G. \& Gradstein, F.M., 2008. The concise geologic time scale. Cambridge University Press, Cambridge, $177 \mathrm{pp}$.
Orlov, I.V. \& Bespalov, V.F. (Eds), 1981. Geologitcheskaja karta Kazakhskoj SSR. Serija Tsentral'no-Kazakhstanskaja. Ob'jasnitel'naja zapiska [Geological map of the Kazakh SSR. Central Kazakhstan Series. Descriptive note]. VSEGEI, Alma-Ata, 247 pp. (in Russian)

Peters, S.E. \& Foote, M., 2001. Biodiversity in the Phanerozoic: a reinterpretation. Paleobiology 27, 583-601.

Purdy, E.G., 2008. Comparison of taxonomic diversity, strontium isotope and sea-level patterns. International Journal of Earth Sciences 97, 651-664.

Racki, G., 2005. Towards understanding Late Devonian global events: few answers, many questions. [In:] D.J. Over, J.R. Morrow \& P.B. Wignall (Eds): Understanding Late Devonian and Permian-Triassic biotic and climatic events: towards an integrated approach. Elsevier, Amsterdam, pp. 5-36.

Racki, G., 2009. Wielkie wymierania i ich przyczyny [Great extinctions and their origin]. Kosmos 58, 529-545.

Racki, G., Racka, M., Matyja, H. \& Devleeschouwer, X., 2002. The Frasnian/Famennian boundary interval in the South Polish-Moravian shelf basins: integrated event-stratigraphical approach. Palaeogeography, Palaeoclimatology, Palaeoecology 181, 251-297.

Raup, D.W. \& Sepkoski, J.J., 1982. Mass extinctions in the marine fossil record. Science 215, 1501-1503.

Ruban, D.A., 2005. Mesozoic marine fossil diversity and mass extinctions: an experience with the middle XIX century paleontological data. Revue de Paléobiologie 24, 287-290.

Ruban, D.A. \& Van Loon, A.J., 2008. Possible pitfalls in the procedure for paleobiodiversity-dynamics analysis. Geologos 14, 37-50.

Ruban, D.A., Al-Husseini, M.I. \& Iwasaki, Y., 2007. Review of Middle East Paleozoic plate tectonics. GeoArabia $12,35-56$.

Scotese, C.R., 2004. A continental drift flipbook. Journal of Geology 112, 729-741.

Şengör, A.M.C. \& Natal'in, B.A., 1996. Paleotectonics of Asia: fragments of a synthesis. [In:] A. Yin \& M. Harris (Eds): The tectonic evolution of Asia. Cambridge, University Press, pp. 486-640.

Sepkoski, J.J., 1993. Ten years in the library: new data confirm paleontological patterns. Paleobiology 19, 43-51.

Sepkoski, J.J., 2002. A compendium of fossil marine animal genera. Bulletins of American Paleontology 363, $1-560$.

Sepkoski, J.J., Bambach, R.K., Raup, D.M. \& Valentine, J.W., 1981. Phanerozoic marine diversity and fossil record. Nature 293, 435-437.

Stampfli, G.M. \& Borel, G.D., 2002. A plate tectonic model for the Paleozoic and Mesozoic constrained by dynamic plate boundaries and restored synthetic oceanic isochrons. Earth and Planetary Science Letters 196, 17-33.

Torsvik, T.H. \& Cocks, L.R.M., 2004. Earth geography from 400 to $250 \mathrm{Ma}$ : a palaeomagnetic, faunal and facies review. Journal of the Geological Society, London $161,555-572$.

Tuljaganov, Kh.T. \& Jaskovitch, B.V., 1980. Geologitcheskaja karta Uzberkskoj SSR [Geological map of Uzbek SSR]. Fan, Tashkent, 200 pp. (in Russian). 
Veimarn, A.B., Kuzmin, A.V. \& Vorontsova, T.N., 1997. Geologitcheskie sobytija v Kazakhstane na rubezhe franskogo i famenskogo vekov i ikh znatchenie v rjadu global'nykh sobytij etogo vremenii [Geological events in Kazakhstan at the boundary of the Frasnian and the Famennian and their significance within the row of events of the pertinent time]. Bulletin of Moscow Society of Naturalists, Geological Series 72 (4), 35-46. (in Russian).

Wall, P.D., Ivany, L.C. \& Wilkinson, B.H., 2009. Revisiting Raup: exploring the influence of outcrop area on diversity in light of modern sample standardization techniques. Paleobiology 35, 146-167.

Walliser, O.H., 1996. Global events in the Devonian and Carboniferous. [In:] O.H. Walliser (Ed): Global events and event stratigraphy in the Phanerozoic. Berlin, Springer, pp. 225-250.

Wang, K., Orth, K.J., Attrep Jr., M., Chatterton, B.D.E., Hou, H. \& Geldsetzer, H.H.J., 1991. Geochemical evidence for a catastrophic biotic event at the Frasnian/ Famennian boundary in south China. Geology 19, 776-779.

Zhamojda, A.I. (Ed), 1968. Geologitcheskoje strojenije SSSR. Vol. 1. Stratigrafija [Geological structure of the USSR. Vol. 1. Stratigraphy]. Nedra, Moskva, 709 pp. (in Russian).

Manuscript received 5 September 2010 revision accepted 18 February 2011 
Appendix 1. Stratigraphic distribution of Middle Devonian-Mississippian marine genera in central Kazakhstan. Data are compiled from Bespalov \& Kostenko (1981a,b) and Orlov \& Bespalov (1981). Data are given 'as is' without taxonomic corrections. See text for an explanation of the probabilistic approach of documentation of taxa ranges.

\begin{tabular}{|c|c|c|c|c|c|c|c|c|c|c|c|c|c|c|c|}
\hline Genera & 㫯 & 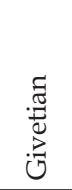 & 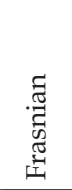 & 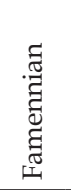 & 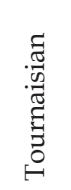 & $\begin{array}{l}\approx \\
\widetilde{\Xi} \\
: \\
:\end{array}$ & 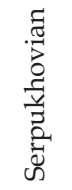 & Genera & 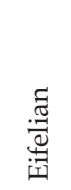 & 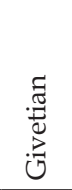 & 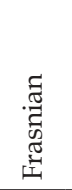 & 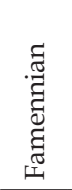 & 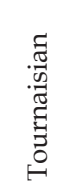 & 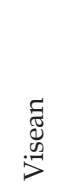 & 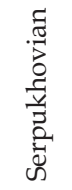 \\
\hline Acanthosphaera & 1.00 & & & & & & & Camarotoechia & 1.00 & & 1.00 & 0.50 & 1.00 & 1.00 & 0.50 \\
\hline Acantophyllum & 1.00 & & & & & & & Campophyllum & & 0.50 & 0.50 & & & & \\
\hline Acratia & & & & & 1.00 & & & Cancrinella & & & & & & 1.00 & \\
\hline Acratina & & & & & 1.00 & & & Caninia & & & & & 1.00 & 1.00 & 0.50 \\
\hline Acrospirifer & 1.00 & & & & & & & Capulus & & & & & 1.00 & & \\
\hline Actinostroma & 1.00 & 1.00 & & & & & & Carbonita & & & & & 1.00 & & \\
\hline Adolfia & & & 1.00 & & & & & Carinatina & 0.50 & & & & & & \\
\hline Allorisma & & & & & 1.00 & 1.00 & & Cariniferella & & 1.00 & 1.00 & & & & \\
\hline Alveolitella & & 1.00 & & & & & & Carposphaera & 1.00 & & & 0.50 & 0.50 & & \\
\hline Alveolites & 1.00 & 1.00 & 1.00 & & & & & Cavellina & & & & & & 1.00 & \\
\hline Ambocoelia & & & & & 1.00 & & & Cenellipsis & 1.00 & & & 0.50 & 0.50 & & \\
\hline Ammodiscus & & & & & & 1.00 & & Cenosphaera & & & & 0.50 & 0.50 & & \\
\hline Amphipora & & 1.00 & & & & & & Ceratoikiscum & & & 1.00 & & & & \\
\hline Amphisphaera & & & & 0.50 & 0.50 & & & Chaetetes & & & & & & 1.00 & \\
\hline Amplexocarinia & & & & & & & 0.50 & Chamishaella & & & & & 1.00 & 1.00 & \\
\hline Anopliopsis & & & & & & 0.50 & 0.50 & Cheiloceras & & & & 1.00 & & & \\
\hline Anthracoceras & & & & & & & 1.00 & Chonetes & 0.50 & & 0.50 & 0.50 & 1.00 & 1.00 & 0.50 \\
\hline Antiquatonia & & & & & & 1.00 & 0.50 & Cladopora & 0.50 & & & & & & \\
\hline Antostylostroma & 0.50 & & & & & & & Clathrocoilona & & 1.00 & & & & & \\
\hline Aparchites & & & & & 1.00 & & & Clorinda & 0.50 & & & & & & \\
\hline Arachalasma & & & & & & 1.00 & & Coenites & 0.50 & 0.50 & 0.50 & & & & \\
\hline Arcanoceras & & & & & & 1.00 & & Composita & & & & & 1.00 & 1.00 & 1.00 \\
\hline Archaediscus & & & & & & 1.00 & 0.50 & Conularia & & & & & & 1.00 & \\
\hline Archaeosphaera & & & & 1.00 & 1.00 & & & Crassialveolites & & 1.00 & & & & & \\
\hline Asteroarchaediscus & & & & & & 0.50 & 0.50 & Cravenoceras & & & & & & & 1.00 \\
\hline Asterosphaera & & & & & 1.00 & & & Cromyosphaera & & & & 0.50 & 0.50 & & \\
\hline Astroentactinia & & & 1.00 & & & & & Cryptonella & & & 1.00 & & & & \\
\hline Astrophyllum & & 1.00 & & & & & & Cyathocarinia & & & & & & & 0.50 \\
\hline Atelodictyon & & 1.00 & & & & & & Cyclocyclicus & & 1.00 & & & & & \\
\hline Athyris & & & 1.00 & 1.00 & 1.00 & 1.00 & 0.50 & Cypricardinia & & & & & 1.00 & 1.00 & \\
\hline Atrypa & 0.50 & 1.00 & 1.00 & 0.50 & & & & Cyrtina & 1.00 & & & & & & \\
\hline Aulacella & & & & & 1.00 & & & Cyrtiopsis & & & 1.00 & 1.00 & & & \\
\hline Aulacophyllum & & 0.50 & 0.50 & & & & & Cyrtospirifer & & & 1.00 & 1.00 & 1.00 & & \\
\hline Aulophyllum & & & & & & 0.50 & 0.50 & Cyrtosymbole & & & & 1.00 & & & \\
\hline Aviculopecten & & & & & & 1.00 & 0.50 & Dalmanella & & & 0.50 & 0.50 & & & \\
\hline Avonia & & & & & 1.00 & 1.00 & 0.50 & Delthyris & 1.00 & & & & & & \\
\hline Bairdia & & & & & 1.00 & & & Dentatrypa & 0.50 & & & & & & \\
\hline Bairdiocypris & & & & & 1.00 & & & Dibunophyllum & & & & & & 0.50 & 0.50 \\
\hline Beyrichoceras & & & & & & 1.00 & & Dichotrypa & & & & & & & 0.50 \\
\hline Bisphaera & & & & & 1.00 & 0.50 & & Dictyoclostus & & & & & 1.00 & 1.00 & 0.50 \\
\hline Bitubertina & & & 1.00 & & & & & Dielasma & & & & & & 1.00 & \\
\hline Brachimetopus & & & & & 1.00 & & & Discritella & & 0.50 & 0.50 & & & & \\
\hline Brachyspirifer & & 0.50 & 1.00 & & & & & Dombardites & & & & & & 0.50 & 0.50 \\
\hline Brachythyris & & & & & 1.00 & 1.00 & & Dorysphaera & & & & 0.50 & 0.50 & & \\
\hline Bucania & & & & & & 1.00 & & Drevermannia & & & & 1.00 & & & \\
\hline Buxtonia & & & & & & 1.00 & 0.50 & Earlandia & & & & & 1.00 & 0.50 & \\
\hline Calceola & 1.00 & & & & & & & Echinoconchus & & & & & & 0.50 & 0.50 \\
\hline Calcisphaera & & & & & 1.00 & & & Edmondia & & & & & & 1.00 & \\
\hline
\end{tabular}




\begin{tabular}{|c|c|c|c|c|c|c|c|c|c|c|c|c|c|c|c|}
\hline Genera & 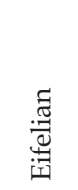 & 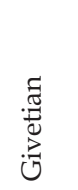 & 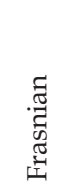 & 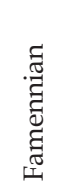 & 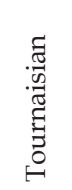 & $\begin{array}{l}\text { ฮే } \\
\stackrel{0}{5} \\
;\end{array}$ & 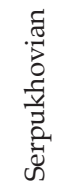 & Genera & 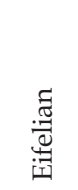 & 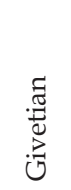 & 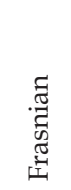 & 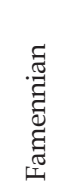 & 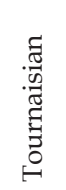 & 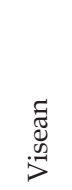 & 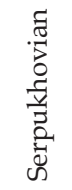 \\
\hline Edmondiella & & & & & & 1.00 & & Imbrexia & & & & & 1.00 & & \\
\hline Ellipsidium & 1.00 & & & & & & & Imitoceras & & & & & 1.00 & & \\
\hline Ellipsoxiphus & & & & 0.50 & 0.50 & & & Inflatia & & & & & & & 1.00 \\
\hline Elytha & 1.00 & & & & & & & Ivdelinia & 0.50 & & & & & & \\
\hline Elythina & & 1.00 & & & & & & Jonessina & & & & & 1.00 & 1.00 & \\
\hline Emanuella & & 1.00 & & & & & & Joungiella & & & & & 1.00 & 1.00 & \\
\hline Enantiosphen & & 1.00 & & & & & & Karadjalia & & & & & 1.00 & 1.00 & \\
\hline Endothyra & & & & & & 0.50 & 0.50 & Karpinskia & 0.50 & & & & & & \\
\hline Endothyranopsis & & & & & & 1.00 & 0.50 & Kasakhstanodiscus & & & & & & 1.00 & \\
\hline Entactinia & & & 1.00 & & & & & Kazakhoceras & & & & & & & 1.00 \\
\hline Entactinosphaera & & & 1.00 & & & & & Kazakhstania & & & & & 1.00 & & \\
\hline Eoendothyra & & & & & 1.00 & & & Kosmoclymenia & & & & 1.00 & & & \\
\hline Eomarginifera & & & & & & 1.00 & & Laevigites & & & & 1.00 & & & \\
\hline Eospirifer & 0.25 & & & & & & & Lamellispirifer & & & 1.00 & & & & \\
\hline Eostaffella & & & & & 1.00 & 1.00 & 1.00 & Leiorhynchus & & & & 1.00 & & & \\
\hline Eostaffellina & & & & & & 1.00 & 0.50 & Leptagonia & & & & & 1.00 & & \\
\hline Eotuberitina & & & & & 1.00 & & & Leptostrophia & & 0.50 & 0.50 & & & & \\
\hline Eumphalus & & & & & 1.00 & & & Lingula & & & & & & 1.00 & 1.00 \\
\hline Euphemites & & & & & & 1.00 & & Linoproductus & & & & & 1.00 & 1.00 & 1.00 \\
\hline Euryspirifer & 0.50 & 1.00 & & & & & & Lioclema & & 0.50 & 0.50 & & & & \\
\hline Fabalicypris & & & & & 1.00 & & & Liosphaera & & & & 0.50 & 0.50 & & \\
\hline Fasciphyllum & 0.50 & 1.00 & & & & & & Lithapium & & & & 0.50 & 0.50 & & \\
\hline Favosites & 1.00 & 1.00 & & & & & & Lithostrotion & & & & & & 1.00 & 0.50 \\
\hline Fenestella & & & & & 1.00 & 1.00 & 0.50 & Littiotubella & & & & & 1.00 & & \\
\hline Fistulipora & & & & & & 1.00 & & Loeblichia & & & & & & & 1.00 \\
\hline Fluctuaria & & & & & & 1.00 & 0.50 & Loxonema & & & & & & 1.00 & \\
\hline Forschia & & & & & & 1.00 & & Manticoceras & & & 1.00 & & & & \\
\hline Fusella & & & & & 1.00 & & & Maoristrophia & 0.25 & & & & & & \\
\hline Gangamophyllum & & & & & & 0.50 & 0.50 & Marginatia & & & & & 1.00 & 1.00 & \\
\hline Gattendorfia & & & & & 1.00 & & & Marginifera & & & & & & 1.00 & 0.50 \\
\hline Gigantoproductus & & & & & & 0.50 & 1.00 & Martinia & & & & & 0.50 & 1.00 & 0.50 \\
\hline Girtyoceras & & & & & & 1.00 & & Megachonetes & & & & & & 0.50 & 0.50 \\
\hline Globivalvulina & & & & & & 0.50 & 0.50 & Mesoplica & & & & 1.00 & 1.00 & & \\
\hline Globoendothyra & & & & & & 0.50 & 0.50 & Metaconites & & & & & & 0.50 & 0.50 \\
\hline Glomospira & & & & & 1.00 & & & Microcheilinella & & & & & 1.00 & 1.00 & \\
\hline Glyptopleura & & & & & & 1.00 & 0.50 & Moorites & & & & & 1.00 & 1.00 & \\
\hline Goldius & & 1.00 & & & & & & Mourlonia & & & & & 1.00 & 1.00 & 0.50 \\
\hline Goniatites & & & & & & 1.00 & 0.50 & Mucrospirifer & & 1.00 & 1.00 & & & & \\
\hline Grandispirifer & & & & & & 1.00 & & Muenstroceras & & & & & & 1.00 & \\
\hline Grypophyllum & & 1.00 & 0.50 & & & & & Myalina & & & & & & 1.00 & \\
\hline Gypidula & & 1.00 & 1.00 & & & & & Nanicella & & & 1.00 & & & & \\
\hline Hamlingella & & & & & 1.00 & & & Neoarchaediscus & & & & & & 0.50 & 0.50 \\
\hline Haplothecia & & 1.00 & & & & & & Neospirifer & & & & & & 1.00 & 1.00 \\
\hline Healdia & & & & & 1.00 & 1.00 & & Neostringophyllum & & 1.00 & & & & & \\
\hline Healdianella & & & & & 1.00 & 1.00 & & Neotuberitina & & & & & 1.00 & 0.50 & 0.50 \\
\hline Hemitrypa & & 0.50 & 0.50 & & & & & Nicholsoniella & & 1.00 & & & & & \\
\hline Hexalonche & 1.00 & & & 0.50 & 0.50 & & & Nodosinella & & & 1.00 & 0.30 & 0.30 & & \\
\hline Hollinella & & & & & & 1.00 & & Nucula & & & & & & 1.00 & \\
\hline Homoceras & & & & & & & 1.00 & Numismoceras & & & & & & 1.00 & \\
\hline Howchinia & & & & & & 1.00 & 0.50 & Omphalotis & & & & & & 0.50 & 0.50 \\
\hline Hyperammina & & & & & & 0.50 & 0.50 & Orbiculoidea & & & & & & 1.00 & 1.00 \\
\hline Hypothyridina & & & 1.00 & & & & & Orthotetes & & & & & 0.50 & 1.00 & \\
\hline
\end{tabular}




\begin{tabular}{|c|c|c|c|c|c|c|c|c|c|c|c|c|c|c|c|}
\hline Genera & 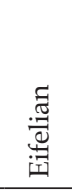 & $\begin{array}{l}\stackrel{\Xi}{0} \\
\stackrel{0}{0} \\
\stackrel{0}{0}\end{array}$ & 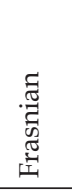 & 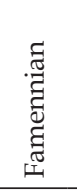 & 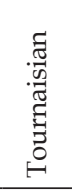 & 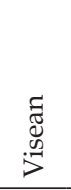 & 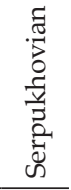 & Genera & 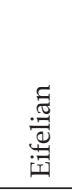 & 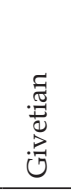 & 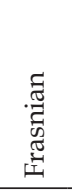 & 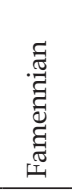 & 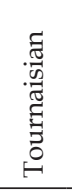 & 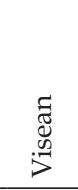 & 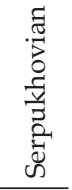 \\
\hline Ovatia & & & & & 1.00 & 1.00 & 0.50 & Pugnax & & & 1.00 & 0.50 & & & \\
\hline Overtonia & & & & & & 0.50 & 0.50 & Pugnoides & & & 1.00 & & & & \\
\hline Pachyfavosites & & 1.00 & & & & & & Punctospirifer & & & & & & & 1.00 \\
\hline Palaeoscenidium & & & 1.00 & & & & & Pustula & & & & & 1.00 & & \\
\hline Palaeosmilia & & & & & & 0.50 & 0.50 & Quasiendothyra & & & & & 1.00 & & \\
\hline Paragoniatites & & & & & & 0.50 & 0.50 & Quasifusulina & & & & & 1.00 & & \\
\hline Paralithostration & & & & & & 0.50 & 0.50 & Radiosphaera & & & & & 1.00 & & \\
\hline Parallelodon & & & & & 1.00 & & & Reteporidra & & 0.50 & 0.50 & & & & \\
\hline Parallelopora & & 1.00 & & & & & & Retichonetes & & & & & 1.00 & & \\
\hline Paraparchites & & & & & 1.00 & 1.00 & 0.50 & Reticularia & & & & & & 0.50 & 0.50 \\
\hline Parathurammina & & & 1.00 & 1.00 & 1.00 & 0.50 & 0.50 & Reticulariopsis & & & 1.00 & & & & \\
\hline Pentagonocyclis & & 1.00 & & & 1.00 & & & Rhineoderma & & & & & & 1.00 & 0.50 \\
\hline Pericyctus & & & & & & 1.00 & & Rhipidomella & & & & & & 1.00 & \\
\hline Phacopidella & & & & 1.00 & & & & Rhodosphaera & & & & 0.50 & 0.50 & & \\
\hline Phacops & & & & 1.00 & & & & Richterina & & & & & 1.00 & & \\
\hline Pinacites & 1.00 & & & & & & & Ridderia & 1.00 & & & & & & \\
\hline Placocoenites & 0.50 & 1.00 & & & & & & Rotaia & & & & & 1.00 & & \\
\hline Plagioniscus & 1.00 & & & & & & & Rugosochonetes & & & & & 1.00 & 1.00 & \\
\hline Planoarchaediscus & & & & & & 1.00 & & Sagittoceras & & & & & & 1.00 & 0.50 \\
\hline Planodiscus & & & & & & 1.00 & & Sanguinolites & & & & & & 1.00 & 0.50 \\
\hline Planoendothyra & & & & & 1.00 & & & Schellwienella & 1.00 & & & & & & \\
\hline Platyclymenia & & & & 1.00 & & & & Schisophoria & & 1.00 & 0.50 & 0.50 & 1.00 & 1.00 & \\
\hline Plectogyra & & & & & 1.00 & 1.00 & 0.50 & Schizodus & & & & & & 1.00 & \\
\hline Plectogyrina & & & & & 1.00 & & & Scrobicula & & & & & & 1.00 & \\
\hline Plectorhynchella & & & 1.00 & 1.00 & & & & Selebratina & & & & & 1.00 & & \\
\hline Plicatifera & & & & 1.00 & 1.00 & 1.00 & 0.50 & Semiplanus & & & & & & 0.50 & 0.50 \\
\hline Plicochonetes & & & & & 1.00 & & & Sentosia & & & & & 1.00 & & \\
\hline Polidevcia & & & & & & 1.00 & 0.50 & Septabrunsiina & & & & & 1.00 & & \\
\hline Polyentactinia & & & 1.00 & & & & & Septaglomospiranella & & & & & 1.00 & & \\
\hline Polypora & & 0.50 & 0.50 & & 1.00 & & & Septatournayella & & & & & 1.00 & & \\
\hline Posidonia & & & & & 1.00 & 1.00 & 1.00 & Serenida & & & & & 1.00 & & \\
\hline Prionoceras & & & & 1.00 & & & & Simplexodictyon & & 1.00 & & & & & \\
\hline Productella & & 0.50 & 1.00 & & 1.00 & & & Sinuatella & & & & & & 1.00 & \\
\hline Productina & & & & & 1.00 & & & Siphonophyllia & & & & & 1.00 & & \\
\hline Productus & & & & & 1.00 & 1.00 & 1.00 & Somphoentactinia & & & 1.00 & & & & \\
\hline Progonioclymenia & & & & 1.00 & & & & Sphaerostylus & & & & 0.50 & 0.50 & & \\
\hline Prolecanites & & & & & & 1.00 & 0.50 & Sphaerozoum & & & & 0.50 & 0.50 & & \\
\hline Prolobites & & & & 1.00 & & & & Sphenospira & & & & & 1.00 & & \\
\hline Pronorites & & & & & & 1.00 & & Spinocyrtia & & 1.00 & 1.00 & & & & \\
\hline Propermodiscus & & & & & & 1.00 & & Spinulicosta & & 1.00 & & & 1.00 & & \\
\hline Proshumardites & & & & & & & 1.00 & Spirifer & 1.00 & & & & 1.00 & 1.00 & 0.50 \\
\hline Protocanites & & & & & 1.00 & & & Spiriferina & & & & & 1.00 & 1.00 & 0.50 \\
\hline Protolepitostrophia & & 1.00 & & & & & & Spiroplectammina & & & & & & 0.50 & 0.50 \\
\hline Protoschizodus & & & & & & 1.00 & & Spongasphaera & 1.00 & & & & & & \\
\hline Pseudobatostomella & & 0.50 & 0.50 & & & & & Spongentactinella & & & 1.00 & & & & \\
\hline Pseudochonophyllum & 0.50 & & & & & & & Spongophyllum & & 1.00 & & & & & \\
\hline Pseudoendothyra & & & & & & 0.50 & 0.50 & Sporadoceras & & & & 1.00 & & & \\
\hline Pseudoleiorhynchus & & & & 1.00 & & & & Squameofavosites & 0.50 & & & & & & \\
\hline Pseudomussium & & & & & & 1.00 & & Squamularia & & & & & & 1.00 & \\
\hline Pterynopecten & & & & & 1.00 & & & Staurolonche & 1.00 & & & 0.50 & 0.50 & & \\
\hline Ptilopora & & & & & 1.00 & & & Stauropruppa & & & & 0.50 & 0.50 & & \\
\hline Pugilis & & & & & & 1.00 & 1.00 & Staurosphaera & & & & 0.50 & 0.50 & & \\
\hline
\end{tabular}




\begin{tabular}{|c|c|c|c|c|c|c|c|c|c|c|c|c|c|c|c|}
\hline Genera & 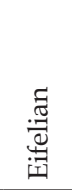 & 怘 & 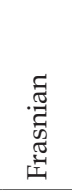 & 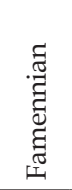 & 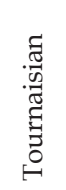 & 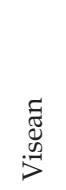 & 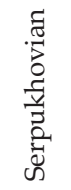 & Genera & 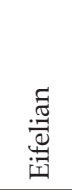 & 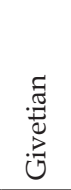 & 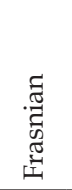 & 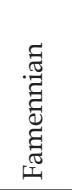 & 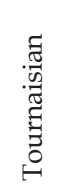 & 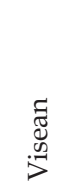 & 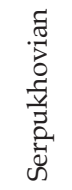 \\
\hline Stellopora & & 1.00 & & & & & & Tomiepsis & & & & & & 1.00 & \\
\hline Stereophyllum & 0.50 & & & & & & & Torynifer & & & & & 1.00 & 1.00 & \\
\hline Streptorynchus & & & & & & 1.00 & & Tylothyris & & & & & 1.00 & 1.00 & \\
\hline Striatifera & & & & & & 1.00 & 0.50 & Typhloproetus & & & & 1.00 & 1.00 & & \\
\hline Striatopora & & 0.50 & 0.50 & & & & & Tyrganolites & 1.00 & & & & & & \\
\hline Stringocephalus & & 1.00 & & & & & & Uchtovia & & & & & 1.00 & & \\
\hline Stromatopora & 0.50 & 1.00 & & & & & & Umbella & & & 1.00 & & & & \\
\hline Stropheodonta & 1.00 & 1.00 & 1.00 & 0.50 & & & & Uncinulus & 0.50 & 1.00 & & & & & \\
\hline Sulcoretopora & & & & & & 0.50 & 0.50 & Verkhotomia & & & & & & 1.00 & 0.50 \\
\hline Syringopora & & & & & & 1.00 & & Vicinesphaera & & & & & 1.00 & & \\
\hline Syryngothyris & & & & & 1.00 & & & Waagenoconcha & & & & & 1.00 & 0.50 & \\
\hline Tabulophyllum & & 1.00 & 0.50 & & & & & Whidbornella & & & & & 1.00 & & \\
\hline Tenisia & & & & & 1.00 & & & Xiphosphaera & & & & 0.50 & 0.50 & & \\
\hline Tetrataxis & & & & & & 1.00 & 0.50 & Xiphostylus & & & & 0.50 & 0.50 & & \\
\hline Thamnopora & 1.00 & 0.50 & 0.50 & & & & & Yunnanellina & & & & 1.00 & & & \\
\hline Thecosphaera & & & & 0.50 & 0.50 & & & Zilimia & & & & 1.00 & & & \\
\hline Theodossia & 0.50 & & 1.00 & & & & & Zonophyllum & & 1.00 & & & & & \\
\hline
\end{tabular}

Appendix 2. Stratigraphic distribution of Middle Devonian-Mississippian marine genera in Uzbekistan. Data are compiled from Tuljaganov \& Jaskovitch (1980). Data are given 'as is' without taxonomic corrections. See text for an explanation of the probabilistic approach of the documentation of taxa ranges.

\begin{tabular}{|c|c|c|c|c|c|c|c|c|c|c|c|c|c|c|c|}
\hline Genera & 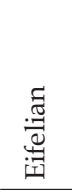 & 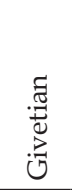 & 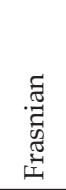 & 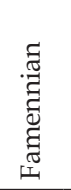 & 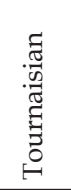 & 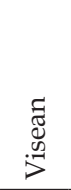 & 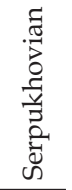 & Genera & 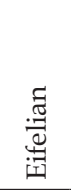 & 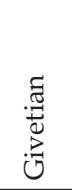 & 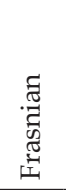 & 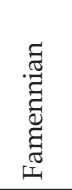 & 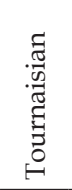 & 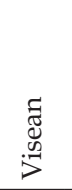 & 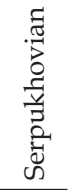 \\
\hline Acanthophyllum & 1.00 & & & & & & & Camarotoechia & 1.00 & & & 1.00 & 1.00 & 1.00 & $\overline{0.50}$ \\
\hline Actinostroma & 0.25 & 1.00 & 0.50 & 0.50 & & & & Campophyllum & 1.00 & & & & & & \\
\hline Adolfia & & & 1.00 & & 1.00 & & & Cancrinella & & & & & & 1.00 & \\
\hline Alveolites & 0.20 & 1.00 & & & & & & Caninia & & & & & & 1.00 & \\
\hline Ammodiscus & & & & & & 1.00 & 0.50 & Carinatina & 1.00 & 1.00 & 1.00 & & & & \\
\hline Amphipora & 1.00 & 1.00 & 1.00 & 0.50 & & & & Chaetetes & 0.50 & 0.50 & & & & 1.00 & \\
\hline Amplexus & & & & & & 1.00 & & Chonetepustula & & & 1.00 & & & 1.00 & 0.50 \\
\hline Anatrypa & & 1.00 & & & & & & Chonetes & 1.00 & & & 1.00 & 1.00 & 1.00 & 0.50 \\
\hline Aranariocrinus & & & & & & & 0.50 & Choristites & & & & & & & 0.50 \\
\hline Archaediscus & & & & & & 1.00 & 1.00 & Cladopora & 1.00 & 0.25 & 0.25 & 0.25 & & & \\
\hline Archaesphaera & & & 0.50 & 0.50 & 1.00 & 1.00 & & Clathrodictyon & 0.20 & 0.20 & 0.50 & 0.50 & & & \\
\hline Asteroarchaediscus & & & & & & 1.00 & 1.00 & Clorinda & 1.00 & & & & & & \\
\hline Athyris & & & & & & 1.00 & 0.50 & Coenites & 1.00 & 1.00 & & & & & \\
\hline Atrypa & 1.00 & 1.00 & 1.00 & & & & & Columnaria & 0.20 & 0.20 & & & & & \\
\hline Bakewella & & & & & & & 0.50 & Conchidiella & 1.00 & & 1.00 & & & & \\
\hline Batostomella & & & & & & 1.00 & & Conchidium & 1.00 & & & & & & \\
\hline Bellerophon & & & & 1.00 & & & & Corwenia & & & & & & 1.00 & \\
\hline Bethanyphyllum & 0.25 & & & & & & & Crassialveolites & & 1.00 & & & & & \\
\hline Bisphaera & & & & 0.50 & 1.00 & 1.00 & & Cravenoceras & & & & & & & 0.50 \\
\hline Brachithyris & & & & & & 1.00 & & Cupressocrinus & 1.00 & & & & & & \\
\hline Bradyina & & & & & & & 0.50 & Cyclocyclicus & 0.25 & & & & & 1.00 & \\
\hline Brunsiina & & & & & 1.00 & & & Cyphaspis & 1.00 & & & & & & \\
\hline Buxtonia & & & & & & 1.00 & & Cyrtina & 1.00 & & & & & & \\
\hline Caliopora & 0.20 & 1.00 & 0.30 & 0.30 & & & & Cyrtospirifer & & & 1.00 & 1.00 & 1.00 & & \\
\hline
\end{tabular}




\begin{tabular}{|c|c|c|c|c|c|c|c|c|c|c|c|c|c|c|c|}
\hline Genera & 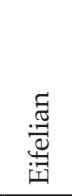 & 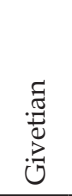 & 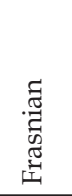 & 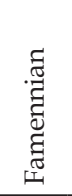 & 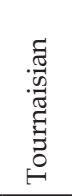 & $\begin{array}{l}\text { ฮี } \\
\stackrel{2}{0} \\
\stackrel{2}{>}\end{array}$ & 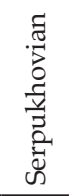 & Genera & 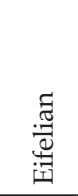 & 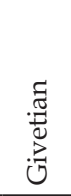 & 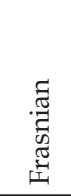 & 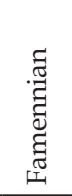 & 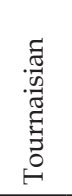 & 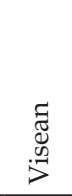 & 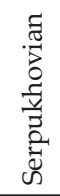 \\
\hline Daviesiella & & & & & 1.00 & 1.00 & & Megalodon & & 1.00 & & & & & \\
\hline Dentatrypa & 1.00 & & & & & & & Megastrophia & 1.00 & & 1.00 & & & & \\
\hline Dialytthophyllum & & 1.00 & & & & & & Millerella & & & & & & & 1.00 \\
\hline Dictyoclostus & & & & & & 1.00 & & Murchisonia & & 1.00 & & & & & \\
\hline Dictyofavosites & 0.20 & 0.20 & & & & & & Neoarchaediscus & & & & & & & 1.00 \\
\hline Dielasma & & & & & 1.00 & 1.00 & 0.50 & Neoglyphiceras & & & & & & & 0.50 \\
\hline Diphyphyllum & & & & & & 1.00 & & Neostringophyllum & & 0.30 & 0.30 & 0.30 & & & \\
\hline Earlandia & & & & & & 1.00 & & Nodocinella & & & 0.50 & 0.50 & & & \\
\hline Echinoconchus & & & & & & 1.00 & & Omphalotis & & & & & & 1.00 & \\
\hline Elytha & & & 1.00 & & & & & Orthoceras & & & & & & & 0.50 \\
\hline Emanuella & 1.00 & 1.00 & 1.00 & & & & & Orthotetes & & & & & & & 0.50 \\
\hline Endothyra & & & & 0.50 & 1.00 & 1.00 & 0.50 & Pachyfavosites & 1.00 & 0.20 & & & & & \\
\hline Endothyranopsis & & & & & & 0.50 & 0.50 & Palaeochoristites & & & & & 1.00 & & \\
\hline Entrochus & 0.25 & 0.20 & & & & & & Palaeosmilia & & & & & & 1.00 & \\
\hline Eoreticularia & 1.00 & 1.00 & & & & & & Paleotextularia & & & & & & 1.00 & \\
\hline Eospirifer & 1.00 & & & & & & & Paralleiopora & & 1.00 & & & & & \\
\hline Eostaffella & & & & & & 1.00 & 1.00 & Parallelodon & & & & & & & 0.50 \\
\hline Eotuberitina & & & & & 1.00 & & & Paramphipora & 1.00 & & 1.00 & & & & \\
\hline Eumorphoceras & & & & & & & 0.50 & Parastaffella & & & & & & 1.00 & 1.00 \\
\hline Fasciphyllum & 0.20 & 0.20 & & & & & & Parathurammina & & 0.30 & 0.50 & 0.50 & 1.00 & 0.50 & \\
\hline Favistella & & 1.00 & & & & & & Pateriocrinus & & & & & & 1.00 & \\
\hline Favosites & 1.00 & 0.20 & 0.50 & 0.50 & & 1.00 & & Pentagonocyclicus & 0.25 & 0.20 & 0.50 & 0.50 & & & \\
\hline Fenestella & & & & & & 0.50 & 0.50 & Perecleites & & & & & & & 0.50 \\
\hline Gephiroceras & & & 1.00 & & & & & Phragmoceris & 1.00 & & & & & & \\
\hline Gigantella & & & & & & 1.00 & & Placocoenites & & 1.00 & & & & & \\
\hline Gigantoproductus & & & & & & 1.00 & 0.50 & Planoendothyra & & & & & & & 0.50 \\
\hline Glaphyrites & & & & & & & 0.50 & Platycrinites & & & & & & & 0.50 \\
\hline Globivalvulina & & & & & & 1.00 & & Plectogyra & & & & & 1.00 & 1.00 & 0.50 \\
\hline Globoendothyra & & & & & 1.00 & 0.50 & 0.50 & Plectospira & 1.00 & & & & & & \\
\hline Glomospira & & & & & & 1.00 & 0.50 & Plectostroma & & 1.00 & & & & & \\
\hline Glomospiranella & & 0.30 & 0.30 & 0.50 & 1.00 & 0.50 & & Plicatifera & & & & 1.00 & 1.00 & & \\
\hline Gryptonella & & 1.00 & & & & & & Praedaraelites & & & & & & & 0.50 \\
\hline Guerechella & & & & & 1.00 & & & Pricodothyris & & & & & & 1.00 & \\
\hline Gypidula & 1.00 & & 1.00 & & & & & Productella & 1.00 & & 1.00 & & & 1.00 & \\
\hline Hexacrinites & 1.00 & & 0.50 & 0.50 & & & & Productus & & 1.00 & & & 1.00 & 1.00 & 0.50 \\
\hline Homoceras & & & & & & & 0.50 & Propermosdiscus & & & & & & 0.50 & 0.50 \\
\hline Hyperammina & & & 0.50 & 0.50 & 1.00 & 1.00 & 0.50 & Protoschizodus & & & & & & & 0.50 \\
\hline Hypothyridina & & & 1.00 & & & & & Pseudostaffella & & & & & & & 0.50 \\
\hline Idiostroma & & 1.00 & & & & & & Pugilis & & & & & & 0.50 & 0.50 \\
\hline Intexodictyon & & & 1.00 & 1.00 & & & & Pugnas & 1.00 & & 1.00 & & & & \\
\hline Karpinskya & 1.00 & & & & & & & Pugnoides & & & & & & 1.00 & \\
\hline Kasachstanocrinus & 1.00 & & & & & & & Pustula & & & & & & 1.00 & \\
\hline Koninkhophyllum & & & & & & 1.00 & & Quasiendothyra & & & & & 1.00 & 0.50 & \\
\hline Krotovia & & & & & & 0.50 & 0.50 & Quasituberitina & & & & & 1.00 & & \\
\hline Latoendothyra & & & & & & 1.00 & & Radiosphaera & & & 0.50 & 0.50 & 1.00 & & \\
\hline Leptaena & 1.00 & & & & & 1.00 & & Reticularia & & & & & & 1.00 & 0.50 \\
\hline Linoproductus & & & & & & 1.00 & 0.50 & Reticuloceras & & & & & & 1.00 & \\
\hline Lissatrypa & 0.20 & 0.20 & & & & & & Rhipidomella & & & & & & 1.00 & \\
\hline Lithostrotion & & & & & & 1.00 & 0.50 & Rhynchonella & 0.20 & 0.20 & & & & & \\
\hline Marginifera & & & & & & 1.00 & 0.50 & Schartymites & & & & & & 1.00 & \\
\hline Martinia & & & & & & 1.00 & & Schellwienella & 0.25 & & & & & 1.00 & \\
\hline Mediocris & & & & & & 1.00 & 0.50 & Schizophoria & 0.25 & & & & 1.00 & 1.00 & \\
\hline
\end{tabular}




\begin{tabular}{|c|c|c|c|c|c|c|c|c|c|c|c|c|c|c|c|}
\hline Genera & 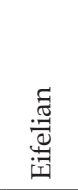 & 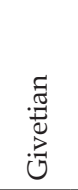 & 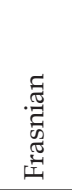 & 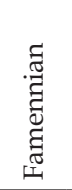 & 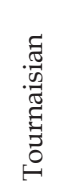 & $\begin{array}{l}\text { శ్ } \\
\stackrel{5}{>} \\
;\end{array}$ & 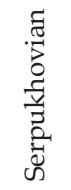 & Genera & 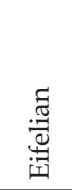 & 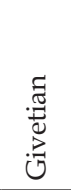 & 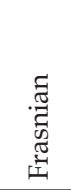 & 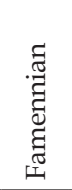 & 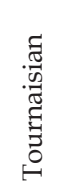 & 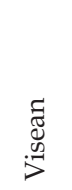 & 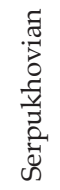 \\
\hline Schuchertella & & & & 1.00 & & & & Striatifera & & & & & & 1.00 & 0.50 \\
\hline Schuguria & & & & & 0.50 & 0.50 & & Stringocephalus & 1.00 & 1.00 & 1.00 & 0.30 & & & \\
\hline Schulgina & & & & & 1.00 & & & Stromatopora & & & 1.00 & & & & \\
\hline Schuteria & & 0.30 & 0.30 & 0.30 & & & & Syringopora & & & & & & & 0.50 \\
\hline Scoliopora & 1.00 & 1.00 & & & & & & Tabulipora & & & & & & & 0.50 \\
\hline Septabrunsiina & & & & & 1.00 & 0.50 & & Tetrataxis & & & & & & 1.00 & 0.50 \\
\hline Septaglomospiranella & & & & & 1.00 & & & Thamnopora & 0.25 & 1.00 & 1.00 & & & 1.00 & \\
\hline Septatournayella & & & & 0.50 & 1.00 & 0.50 & & Theodossia & 1.00 & & 1.00 & 0.50 & & & \\
\hline Sieberella & 0.25 & & & & & & & Thomasina & & & & & & 1.00 & \\
\hline Spirifer & 1.00 & 1.00 & & 0.50 & 1.00 & 1.00 & 0.50 & Thurammina & & & & & 1.00 & & \\
\hline Spiriferina & & & & & & 1.00 & 0.50 & Tornoceras & & & 1.00 & & & & \\
\hline Spirophoria & 1.00 & & & & & & & Triplasma & 1.00 & & & & & & \\
\hline Spiroplectammina & & & & & 1.00 & & & Tuberitina & & & & & 1.00 & 1.00 & \\
\hline Squameofavosites & 0.20 & 0.20 & & & & & & Uncinulus & 1.00 & 1.00 & & & & & \\
\hline Squamularia & & & & & & 0.50 & 0.50 & Uncites & & 1.00 & & & & & \\
\hline Stachyodes & & & 0.50 & 0.50 & & & & Unilineatocrinus & & & & & & & 0.50 \\
\hline Stenopronorites & & & & & & & 0.50 & Visinisphaera & & & 0.50 & 0.50 & 1.00 & 1.00 & \\
\hline Straparollus & & & & 1.00 & & & & Zonophyllum & 0.50 & 0.50 & & & & & \\
\hline
\end{tabular}

Appendix 3. Stratigraphic distribution of Middle Devonian-Mississippian marine genera in Tajikistan. Data are compiled from Baratov (1976). Data are given 'as is' without taxonomic corrections. See text for an explanation of the probabilistic approach of the documentation of taxa ranges.

\begin{tabular}{|c|c|c|c|c|c|c|c|}
\hline Genera & 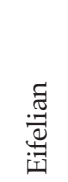 & $\begin{array}{l}\stackrel{\Xi}{\Xi} \\
\stackrel{\Xi}{0} \\
\stackrel{D}{0} \\
0\end{array}$ & 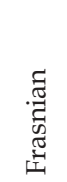 & 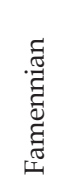 & 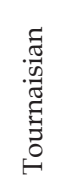 & 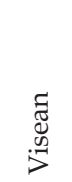 & 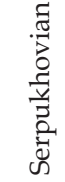 \\
\hline Acanthophyllum & 0.50 & & & & & & \\
\hline Actinostroma & & 1.00 & & & & & \\
\hline Agramatia & & & 1.00 & & & & \\
\hline Ammodiscus & & & & & 1.00 & & \\
\hline Amphipora & 1.00 & 1.00 & 1.00 & & & & \\
\hline Amygdalophyllum & & & & & 0.50 & 0.50 & \\
\hline Anatrypa & & 1.00 & & & & & \\
\hline Antiquatonia & & & & & & & 1.00 \\
\hline Archaediscus & & & & & & 1.00 & 1.00 \\
\hline Archaesphaera & 1.00 & & & & & & \\
\hline Asteroarchaediscus & & & & & & 1.00 & 1.00 \\
\hline Asterosphaera & & & & 1.00 & & & \\
\hline Atrypa & 0.50 & & 1.00 & & & & \\
\hline Aulacophyllum & 0.50 & & & & & & \\
\hline Aulophyllum & & & & & & 1.00 & \\
\hline Bagrassia & & & & 1.00 & & & \\
\hline Bisphaera & 1.00 & & & & & & \\
\hline Bradyina & & & & & & & 1.00 \\
\hline Calceola & 1.00 & & & & & & \\
\hline Caliapora & & 1.00 & & & & & \\
\hline Camarotoechia & & & & & 0.50 & 0.50 & \\
\hline Campophyllum & & & & & 1.00 & & \\
\hline Cancrinella & & & & & & 1.00 & \\
\hline
\end{tabular}

\begin{tabular}{|c|c|c|c|c|c|c|c|}
\hline Genera & 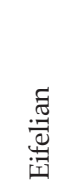 & 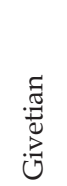 & 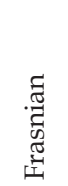 & 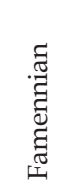 & 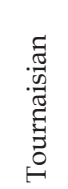 & 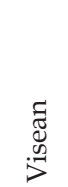 & 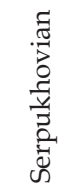 \\
\hline Caninia & & & & & 1.00 & 0.25 & 0.25 \\
\hline Caninophyllum & & & & & & 0.25 & 0.25 \\
\hline Carbonella & & & & & 1.00 & & \\
\hline Carcinophyllum & & & & & & & 1.00 \\
\hline Carinatina & 0.50 & & & & & & \\
\hline Chascothyris & & 1.00 & & & & & \\
\hline Chonetes & & & & & & 0.50 & 1.00 \\
\hline Cladopora & 0.50 & 1.00 & & & & & \\
\hline Clathrodyction & & & 1.00 & & & & \\
\hline Clisiophyllum & & & & & & 0.25 & 0.25 \\
\hline Conchidiella & 1.00 & & & & & & \\
\hline Cravenoceras & & & & & & 0.50 & 1.00 \\
\hline Cupressocrinites & 1.00 & 0.20 & & & & & \\
\hline Cyathoclisia & & & & & 1.00 & & \\
\hline Cyclocyclicus & 1.00 & & & & & & \\
\hline Cymostrophia & 0.50 & & & & & & \\
\hline Cyrtospirifer & & & 1.00 & 1.00 & & & \\
\hline Davisiella & & & & & & 1.00 & \\
\hline Dendrostella & & 1.00 & & & & & \\
\hline Desquamatia & & 1.00 & & & & & \\
\hline Dibunophyllum & & & & & & 1.00 & 0.25 \\
\hline Dictyoclostus & & & & & 1.00 & 1.00 & 1.00 \\
\hline Dimorphoceras & & & & & & 0.50 & 1.00 \\
\hline
\end{tabular}




\begin{tabular}{|c|c|c|c|c|c|c|c|c|c|c|c|c|c|c|c|}
\hline Genera & 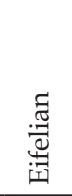 & 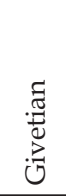 & 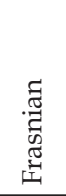 & 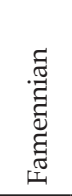 & 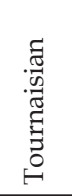 & 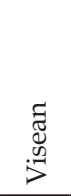 & 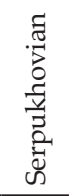 & Genera & 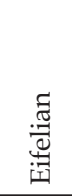 & $\begin{array}{l}\stackrel{0}{ \pm} \\
\stackrel{\Xi}{0} \\
\stackrel{0}{0}\end{array}$ & 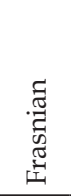 & 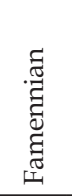 & 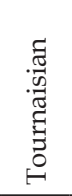 & 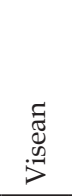 & 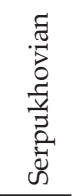 \\
\hline Diphyphyllum & & & & & & 1.00 & & Parathurammina & 1.00 & 1.00 & & 1.00 & 1.00 & & \\
\hline Disphyllum & & & 1.00 & & & & & Pentagonocyclicus & 1.00 & 0.20 & & & & & \\
\hline Earlandia & & & & & 0.50 & 0.50 & & Pentamerella & 0.50 & & & & & & \\
\hline Elytha & & 1.00 & & & & & & Planothyrammina & & & & 1.00 & & & \\
\hline Emanuella & & 1.00 & & & & & & Platygoniatites & & & & & & & 1.00 \\
\hline Endothyra & & & & & 1.00 & 0.50 & & Plectogyra & & & & 1.00 & & 1.00 & 0.50 \\
\hline Eomarginifera & & & & & & & 1.00 & Plicatifera & & & & 1.00 & 1.00 & & \\
\hline Eospirifer & 0.50 & & & & & & & Productella & 1.00 & & & 1.00 & & & \\
\hline Eostaffella & & & & & & 1.00 & 1.00 & Productina & & & & 1.00 & 1.00 & & \\
\hline Eostaffellina & & & & & & & 1.00 & Productus & & & & & 1.00 & 1.00 & 1.00 \\
\hline Eridophyllum & 0.50 & & & & & & & Prolecanites & & & & & & 0.50 & 0.50 \\
\hline Favosites & 1.00 & 1.00 & & & & & & Pseudomicroplasma & & 1.00 & & & & & \\
\hline Forchia & & & & & & 1.00 & & Pseudostaffella & & & & & & & 0.50 \\
\hline Gigantoproductus & & & & & & 1.00 & & Pulilis & & & & & & & 1.00 \\
\hline Glaphyrites & & & & & & 0.50 & 0.50 & Quasiendothyra & & & & & 1.00 & & \\
\hline Globoendothyra & & & & & & 0.50 & 0.50 & Quasiumbella & & & & 1.00 & & & \\
\hline Glomospiranella & & & & & 1.00 & 0.50 & & Rhiphaeccanites & & & & & & 0.50 & 0.50 \\
\hline Glomospirella & & & & & 0.50 & 0.50 & & Schizophoria & & & & & & & 1.00 \\
\hline Goniatites & & & & & & & 1.00 & Schuchertella & & & 1.00 & & & & \\
\hline Heliolites & 1.00 & & & & & & & Semileptagonia & & & 1.00 & & & & \\
\hline Homoceras & & & & & & & 1.00 & Semiplanus & & & & & & 1.00 & \\
\hline Homoceratoides & & & & & & & 1.00 & Septatournayella & & & & & 0.50 & 0.50 & \\
\hline Howchinia & & & & & & 1.00 & & Shellwienella & 0.50 & 1.00 & & & & 0.50 & 0.50 \\
\hline Howellella & 0.50 & & & & & & & Sieberella & 0.50 & & & & & & \\
\hline Karpinskia & 0.50 & & & & & & & Siphonophylla & & & & & 1.00 & & \\
\hline Keyserlingophyllum & & & & & 0.50 & 0.50 & & Spinatrypa & & 1.00 & & & & & \\
\hline Leioproductus & & & & 1.00 & & & & Spinocyrtia & & 1.00 & & & & & \\
\hline Leiorhynchus & & & 0.50 & 0.50 & & & & Spirifer & & & & & 1.00 & 0.50 & 1.00 \\
\hline Linoproductus & & & & & & 1.00 & & Spiroplectammina & & & & 1.00 & 1.00 & & \\
\hline Lithostrotion & & & & & & 1.00 & 0.25 & Squameofavosites & 0.50 & & & & & & \\
\hline Lonsdaleia & & & & & & 1.00 & 1.00 & Striatifera & & & & & & 1.00 & 0.50 \\
\hline Lyrielasma & 0.50 & & & & & & & Stringocephalus & & 1.00 & & & & & \\
\hline Marginifera & & & & & & 0.50 & 1.00 & Syringaxon & & 1.00 & & & & & \\
\hline Martinia & & & & & & 1.00 & & Syringopora & & & & & 0.50 & 1.00 & \\
\hline Mediocrinus & 0.20 & 0.20 & & & & & & Syringostroma & & & 1.00 & & & & \\
\hline Mediocris & & & & & & 1.00 & 0.25 & Tabulophyllum & & 1.00 & & & & & \\
\hline Megachonetes & & & & & & 0.50 & 0.50 & Tetragonocyclicus & 1.00 & 0.20 & & & & & \\
\hline Megastrophia & 1.00 & & & & & & & Textularia & & & & 1.00 & & & \\
\hline Neoarcheodiscus & & & & & & & 1.00 & Thamnopora & 0.50 & & 1.00 & & & & \\
\hline Neospongophyllum & & 1.00 & & & & & & Theodossia & & & 1.00 & & & & \\
\hline Neotuberitina & & & & 1.00 & & & & Tournayella & & & & & 1.00 & 0.50 & \\
\hline Pachycanalicula & 0.50 & & & & & & & Trizonoceras & & & & & & 0.50 & 0.50 \\
\hline Pachyfavosites & 0.50 & 1.00 & & & & & & Tuberitina & & & & 1.00 & & 1.00 & \\
\hline Palaeochoristites & & & & & 1.00 & & & Umbella & & & & 1.00 & & & \\
\hline Palaeosmilia & & & & & & 1.00 & & Uncinulus & 0.50 & & & & & & \\
\hline Paracaligella & & & & 1.00 & & & & Uralopronorites & & & & & & & 1.00 \\
\hline Paragoniatites & & & & & & & 1.00 & Zeravschanocrinus & 0.20 & 0.20 & & & & & \\
\hline
\end{tabular}

